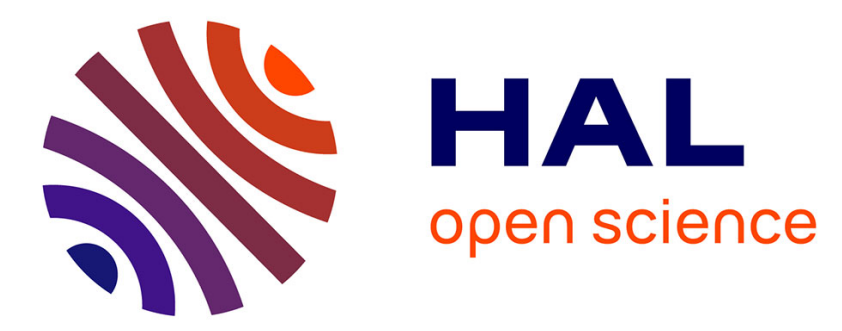

\title{
Enhanced protective response and immunoadjuvant effects of porcine GM-CSF on DNA vaccination of pigs against Aujeszky's disease virus
}

C. Somasundaram, H. Takamatsu, Francois F. Lefèvre, Bernard Charley

\section{- To cite this version:}

C. Somasundaram, H. Takamatsu, Francois F. Lefèvre, Bernard Charley. Enhanced protective response and immunoadjuvant effects of porcine GM-CSF on DNA vaccination of pigs against Aujeszky's disease virus. Veterinary Research, 2000, 31 (1), pp.134-135. hal-02690977

\section{HAL Id: hal-02690977 \\ https: / hal.inrae.fr/hal-02690977}

Submitted on 1 Jun 2020

HAL is a multi-disciplinary open access archive for the deposit and dissemination of scientific research documents, whether they are published or not. The documents may come from teaching and research institutions in France or abroad, or from public or private research centers.
L'archive ouverte pluridisciplinaire HAL, est destinée au dépôt et à la diffusion de documents scientifiques de niveau recherche, publiés ou non, émanant des établissements d'enseignement et de recherche français ou étrangers, des laboratoires publics ou privés. 


\title{
Enhanced protective response and immuno-adjuvant effects of porcine GM-CSF on DNA vaccination of pigs against Aujeszky's disease virus
}

\author{
C. Somasundaram ${ }^{\mathrm{a}}$, H. Takamatsu ${ }^{\mathrm{b}}$, C. Andréoni ${ }^{\mathrm{c}}$, J.-C. Audonnet ${ }^{\mathrm{c}}$, \\ L. Fischer ${ }^{\mathrm{c}}$, F. Lefèvre ${ }^{\mathrm{a}}$, B. Charley, \\ ${ }^{\mathrm{a}}$ Virologie et Immunologie moléculaires, INRA, 78350 Jouy en Josas, France \\ ${ }^{\mathrm{b}}$ Institute for Animal Health, Department of Immunology, Pirbright, UK \\ ${ }^{\mathrm{c}}$ Merial, BioResearch, 69000 Lyon, France
}

Received 7 April 1999; accepted 28 May 1999

\begin{abstract}
This study was conducted to investigate whether the co-delivery of DNA encoding porcine cytokines would enhance a protective immune response in pigs to a Pseudorabies virus (PRV; or Aujeszky's disease virus) DNA vaccine. Aujeszky's disease in pigs results in respiratory and nervous symptoms with important economic losses. To evaluate cytokine effects, eukaryotic expression vectors were constructed for porcine GM-CSF, IL-2 and IFN- $\gamma$. cDNA for each of these cytokines was inserted under the control of a CMV promoter in the pcDNA3 plasmid and cytokine expression was confirmed after DNA transfection in various mammalian cell cultures by bioassays (GM-CSF and IL2) and ELISA (IFN- $\gamma$ ). Pigs were vaccinated by single intramuscular injection with plasmid DNA encoding PRV $\mathrm{gB}$ and $\mathrm{gD}$ along with various combinations of cytokine plasmid constructs. Pig serum was tested for the production of antibody by isotype specific anti-PRV ELISA. Pigs were then challenged with the highly virulent PRV strain NIA3 on day 21 after vaccination. The survival and growth rate of pigs were monitored for seven days after the viral challenge. The co-administration of GM-CSF plasmid increased the immune response induced by $\mathrm{gB}$ and gD PRV DNA vaccine. This immune response was characterized by an earlier appearance of anti-PRV IgG2, a significantly enhanced anti-PRV IgG1 and IgG2 antibody response, a significantly decreased and shortened viral excretion in nasal swabs and an improved protection to the viral challenge. In contrast, the co-administration of porcine IL-2 or IFN- $\gamma$ had no adjuvant effects. Our results thus demonstrate for the first time that the application of porcine GM-CSF gene in a DNA vaccine formulation can exert immuno-adjuvant and protective effects with single
\end{abstract}

\footnotetext{
* Corresponding author. Tel: +331-34-65-26-20; fax: +331-34-65-26-21

E-mail address: charley@biotec.jouy.inra.fr (B. Charley)
} 
vaccination in the natural host pig against Aujeszky's disease. (C) 1999 Elsevier Science B.V. All rights reserved.

Keywords: DNA vaccination; Pseudorabies virus; Pigs; Cytokines; GM-CSF; IL-2; IFN- $\gamma$

\section{Introduction}

The development of more effective and cheap vaccines for economically important domestic animal species such as pig and cattle, is an important task for veterinary immunology, in order to reduce disease induced economical losses. Thus, the induction of strong and long lasting immunity, preferably after administration of a single vaccine, is a key factor in achieving this goal.

DNA immunization is a new vaccination method, by which DNA constructs encoding a specific immunogen are delivered into the host. It is, as compared to the administration of preformed protein antigen, particularly attractive for several reasons (Babiuk et al., 1998; Beard and Mason, 1998): active de novo synthesis of the immunogen in transfected cells is likely to facilitate antigen expression in its native form and antigen presentation by both major histocompatibility complex (MHC) class I and class II molecules (Haynes et al., 1996; Webster et al., 1994). It was also found to be able to generate long term humoral and cellular immune responses (Yankaucka et al., 1993). In addition, this method offers the potential to manipulate the induced immune response through the co-delivery of adjuvants such as cytokine gene constructs, which was shown to enhance the vaccination efficacy (Kim et al., 1997). It also avoids the production and purification of the immunogens. Finally, a major advantage of DNA vaccine is that it does not require cultivation of dangerous infectious agents and is inexpensive to produce and store (Beard and Mason, 1998).

In the present study, we investigated the efficacy of the co-delivery of a few porcine cytokines along with the DNA vaccine formulation for the Pseudorabies virus (PRV, or Aujeszky's disease virus) DNA vaccine. The efficacy was evaluated on the induction of the specific immune response and protection against a viral challenge in the natural host pig. Aujeszky's disease is a serious infectious disease characterised by severe nervous and respiratory symptoms, resulting in decreased weight gains and even death of some animals (Mettenleiter, 1996). Vaccination with the DNA constructs encoding PRV glycoprotein $\mathrm{C}$ (PRV $\mathrm{gC}$ ) or $\mathrm{gD}$ in pigs was previously shown to provide partial protection, for which three successive immunizations were needed (Gerdts et al., 1997; van Rooij et al., 1998). The main purpose of our work was to improve the efficiency of PRV DNA vaccine, in a single injection, by the co-delivery of porcine cytokine genes.

The following cytokines were evaluated in this work: granulocyte-macrophage colony stimulating factor (GM-CSF), interleukin-2 (IL-2) and interferon gamma (IFN- $\gamma$ ). GMCSF is a hemopoietic growth factor that stimulates neutrophil, monocyte/macrophage, and eosinophil colony formation, and increases antibody (Ab)-dependent cell-mediated cytotoxicity (Moore, 1991; Nicola, 1989). Because GM-CSF is able to stimulate and recruit dendritic cells, the most effective antigen presenting cells (APC), it is very attractive as an adjuvant to vaccines (Tao and Levy, 1993). Other cytokines such as IL-2 
and IFN- $\gamma$ have also been shown to be effective in some DNA vaccination protocols (Chen et al., 1994), presumably by inducing the differentiation of Th cells into Th1 cells (Arai et al., 1990). In addition, IFN- $\gamma$ upregulates MHC expression on a variety of cells (Steeg et al., 1982) including myoblasts and myocytes (Hohlfeld and Engel, 1994), which in turn may increase antigen presentation.

Here, we describe that PRV specific immune responses in pigs could be increased by the co-delivery of cytokine genes. More specifically, we demonstrate the efficacy of DNA administered porcine GM-CSF as an adjuvant to increase the immune response to a single DNA vaccine injection, and protection to PRV challenge.

\section{Materials and methods}

\subsection{Cells and viruses}

Porcine kidney cells (PDH and PK15), Rabbit kidney cells (RK13), Swine testis cells (ST) and Chinese hamster ovary (CHO) cells were maintained in Dulbecco's minimum essential medium (DMEM) supplemented with $10 \%$ fetal calf serum (FCS).These cell lines were used for transfecting cDNA plasmid constructs. PRV strain NIA-3 was produced and titrated in PK15 cells as described (Stellman et al., 1989).

\subsection{Construction of plasmids}

Genes encoding porcine GM-CSF (Inumaru and Takamatsu, 1995), IFN- $\gamma$ and IL-2 (Lefèvre, unpublished data) and PRV gB and gD (Audonnet et al., unpublished data), were individually cloned into the eukaryotic plasmid expression vector pcDNA3 (Invitrogen) using standard molecular biology procedures. Constructs were verified by a sequence analysis of the entire insert (on both $5^{\prime}$ and $3^{\prime}$ sides). Plasmids were transformed into the E. coli strain DH5 $\alpha$ and purified using a Qiagen maxipreparation kit (Qiagen, Hilden, Germany) for transfection and purified by cesium chloride centrifugation for injection in pigs. The DNA concentration was estimated by spectrophotometry.

\subsection{Transfection and expression}

To evaluate the expression of porcine GM-CSF, IL-2, IFN- $\gamma$, and PRV gB and gD, cDNA constructs were transfected in PDH, RK13, ST, or COS cells using lipofectAMIN $^{\mathrm{TM}}$ (Life Technologies, Gaithersburg, Maryland). 1-5 $\mu \mathrm{g}$ of DNA was mixed with $15 \mu \mathrm{g}$ of lipofectAMIN ${ }^{\mathrm{TM}}$ reagent and $0.2 \mathrm{ml}$ serum free DMEM or Optimem (Life Technologies); the mixture was kept at room temperature for $30 \mathrm{~min}$, added onto the cells in six well plates and incubated at $37^{\circ} \mathrm{C}$. Cells were washed twice, $6 \mathrm{~h}$ after transfection, in serum free medium and incubated in DMEM with 10\% FCS and antibiotics. For cytokine expression, supernatants were collected 24, 48 and $72 \mathrm{~h}$ after transfection and used for cytokine assays. GM-CSF activity was assessed by a bone marrow proliferation assay (Maliszewski et al., 1988). Briefly, porcine bone marrow cells were incubated with serial dilutions of supernatants and proliferation was measured by ${ }^{3} \mathrm{H}$-thymidine incorporation. A recombinant porcine GM-CSF preparation (Inumaru et 
al., 1998) was included as an internal positive standard. The IL-2 bioassay was performed by ${ }^{3} \mathrm{H}$-thymidine incorporation in porcine activated lymphoblasts as described previously (Charley et al., 1985). We used a PHA activated porcine lymphocyte supernatant as an internal positive standard. IFN- $\gamma$ was measured by a specific ELISA (Lefèvre et al., 1998). The expression of PRV gB and gD was confirmed by Western blot analysis and immunofluorescence on transfected $\mathrm{CHO}$ cells, using anti-gB and $\mathrm{gD}$ monoclonal antibodies (prepared by Merial, Lyon, France). Both glycoproteins were expressed with the expected molecular weight (data not shown).

\subsection{DNA vaccination of pigs and protection assays}

Ten-week-old seronegative crossbred pigs were injected intramuscularly (i.m.) with a total of $2 \mathrm{ml}$ of the plasmid preparation dissolved in $0.9 \% \mathrm{NaCl}$, in a single injection, in the upper part of the neck. Each group of five animals received a total amount of $0.8 \mathrm{mg}$ DNA, which consisted of either pcDNA3 alone (control group), or $0.2 \mathrm{mg} \mathrm{gB}$ plasmid $+0.2 \mathrm{mg}$ gD plasmid $+0.4 \mathrm{mg}$ pcDNA3 plasmid (antigens alone), or $\mathrm{gB}+\mathrm{gD}+0.2 \mathrm{mg}$ GM-CSF + $0.2 \mathrm{mg}$ pcDNA3 plasmids (antigens + GM-CSF), or $\mathrm{gB}+\mathrm{gD}+0.2 \mathrm{mg}$ IL-2 + 0.2 $\mathrm{mg}$ pcDNA3 plasmids (antigens + IL-2), or $\mathrm{gB}+\mathrm{gD}+0.2 \mathrm{mg}$ IFN- $\gamma+0.2 \mathrm{mg}$ pcDNA3 plasmids (antigens + IFN- $\gamma$ ), or $\mathrm{gB}+\mathrm{gD}+0.2 \mathrm{mg}$ GM-CSF + 0.2 mg IL-2 plasmids (antigens + GM-CSF + IL-2), or $\mathrm{gB}+\mathrm{gD}+0.2 \mathrm{mg}$ IL-2 $+0.2 \mathrm{mg}$ IFN- $\gamma$ plasmids (see Figs. 2 and 3). Blood samples were obtained at weekly intervals for serum antibody $(\mathrm{Ab})$ titrations.

For the challenge experiment, the animals were inoculated intranasally on day 21 after vaccination, with the fully virulent NIA-3 strain (1 ml in each nostril of a virus suspension at $10^{8.25} \mathrm{TCID}_{50} / \mathrm{ml}$ ). Clinical signs and body weights were recorded for one week after infection. The mean relative weight gain (MRWG) was calculated between day 21 and day 28 (one week after PRV challenge) or the day of death. The results are expressed in percentage of weight (mean $\pm \mathrm{SD}$ ). The $\Delta \mathrm{G} 7$ value (Stellman et al., 1989) represents the difference between the MRWG of vaccinated and control (pcDNA3) pigs. Virus excretion was monitored by collecting nasal swabs on days $0,3,5$ and 7 after the challenge. The virus was titrated on PK15 cells as described (Vandeputte et al., 1990). The results were expressed as $\log _{10} \mathrm{TCID}_{50} / \mathrm{ml}$ of nasal secretion (mean $\pm \mathrm{SD}$ ).

\section{5. $P R V$ Ab titration}

Neutralizing Ab activity was measured in serum as described (Vandeputte et al., 1990). Anti PRV IgG1 and IgG2 Ab activity was measured by indirect ELISA, using PRV antigen coated microplates (ref 040421 48; Symbiotics, Lyon, France), anti porcine IgG1 and IgG2 monoclonal Ab (refs 7500920 and 7500930; IDDLO, Lelystad, The Netherlands) as the second $\mathrm{Ab}$, and peroxidase labeled anti-mouse Ig as the third $\mathrm{Ab}$.

\subsection{Statistical analysis}

Data were tested for statistical differences by analysis of variance, using the Statgraphics Plus program. 


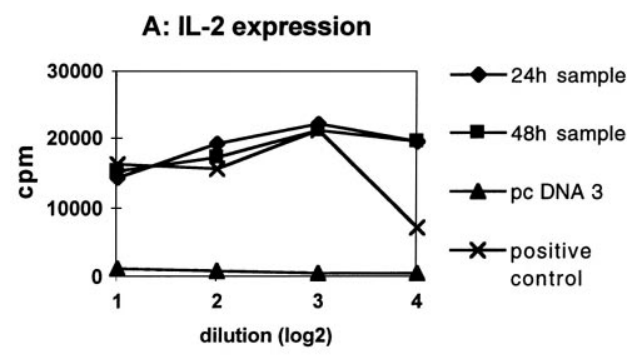

B: IFN gamma expression

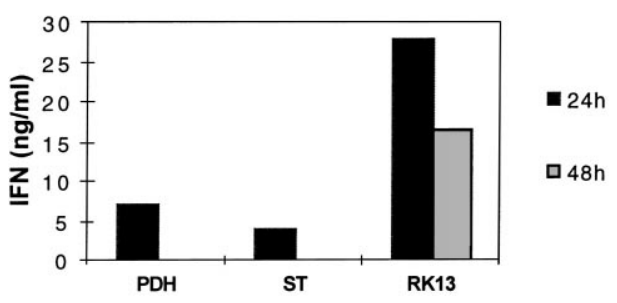

C: GM-CSF expression

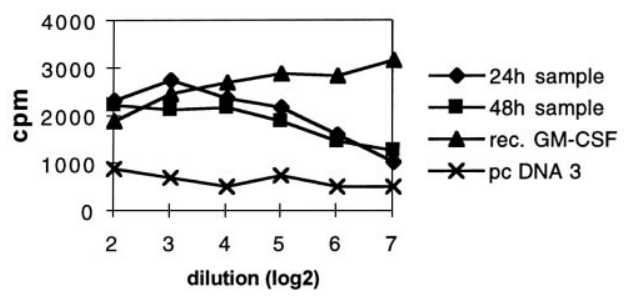

Fig. 1. Expression of porcine cytokine DNA constructs. The cDNA for IL-2 (A), IFN- $\gamma$ (B) and GM-CSF (C) were cloned in the pcDNA3 vector. Plasmids were transfected in PDH (A, B, C), ST or RK13 (B) cells, and the expression of cytokines in supernatants was verified by bioassays (A, C) or by ELISA (B). Positive controls were a PHA supernatant (A) and a recombinant porcine GM-CSF (C) as described in Section 2.

\section{Results}

\subsection{Cytokine secretion in vitro}

After in vitro transfection of plasmid constructs, cell culture supernatants were evaluated for the secretion of the corresponding cytokine. The secretion of all three cytokines was higher at $24 \mathrm{~h}$ than at $48 \mathrm{~h}$ (Fig. 1(B, C)). The biological activity of IL-2 in transfected cells was higher than the positive control (Fig. 1(A)). The level of IFN- $\gamma$ expression varied between cell types. As shown in Fig. 1B the expression of IFN- $\gamma$ was three- to fourfold higher in heterologous rabbit RK13 cells than in homologous porcine ST or PDH cells. No cytokine was detected in supernatants from control pcDNA3 transfected cells. 


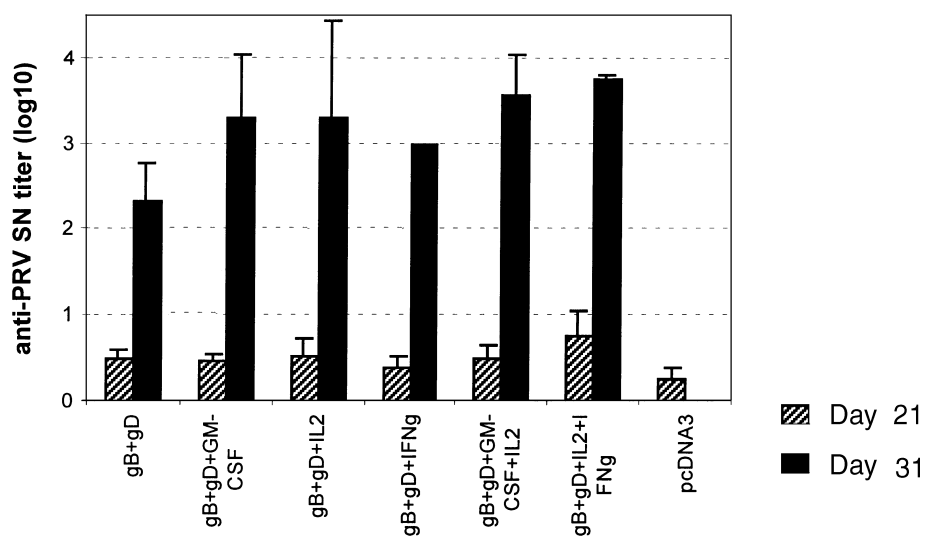

Fig. 2. Virus neutralizing antibody levels at day 21 after the single DNA vaccination and 10 days (day 31 ) after the challenge. The seroneutralization assay was performed on a swine kidney cell line. The titers are expressed in $\log _{10}$ (mean $\pm \mathrm{SD}$ ) of the serum dilution. There was no surviving animal in the pcDNA3 group at day 31 .

\subsection{PRV antibody response in DNA vaccinated pigs}

No neutralizing $\mathrm{Ab}$ was detected at day 21 post-immunization, in any group of pigs examined (Fig. 2). However, neutralizing Ab were detected after challenge (e.g. at day 31, 10 days after challenge: Fig. 2). No significant increase of neutralizing Ab was observed after the co-administration of porcine cytokine DNA.

No $\mathrm{Ab}$ response was detected by isotype specific ELISA seven days after vaccination (data not shown). Seroconversion (IgG1 and IgG2 Ab) was observed in all vaccinated groups, except in pcDNA3 treated control group, at the day 14 after vaccination (Fig. 3). Anti-PRV IgG1 Ab titers were significantly increased in GM-CSF DNA injected pigs, as compared to the other animals ( $p<0.05$ at day 21 , as compared to $\mathrm{gB}+\mathrm{gD}$ injected pigs: Fig. 3). Co-administration of IL-2 DNA with GM-CSF construct abolished the positive effect of GM-CSF alone however the co-administration of the other cytokines alone or in combination had no effects on IgG1 titers (Fig. 3). Anti-PRV IgG2 Ab titers were also significantly increased in GM-CSF treated animals $(p<0.05$, as compared to $\mathrm{gB}+\mathrm{gD}$ alone, at days 14 and 21: Fig. 3). IL-2 co-administration with GM-CSF abolished the enhancing effect on $\mathrm{Ab}$ response. Neither IL-2, nor IFN- $\gamma$, alone or in combination, had any enhancing effect on anti-PRV IgG2 Ab production (Fig. 3).

\subsection{Protection against viral challenge}

Three weeks after a single DNA vaccination, the pigs were challenged with a high dosage $\left(10^{8.25}\right.$ TCID $\left._{50}\right)$ of the NIA-3 fully virulent PRV strain. Virus excretion was followed in nasal swabs three, five and seven days after the challenge. The animals coinjected with GM-CSF showed a significantly lowered and shortened virus production, as compared to the $\mathrm{gB}+\mathrm{gD}$ vaccinated pigs (Fig. 4). At day 7 after challenge, virus was no longer detected in the GM-CSF group, while it was still present in the other groups. IL-2 DNA co-injection inhibited the lowered and shortened virus excretion effect induced by 
Eday 14 day 21

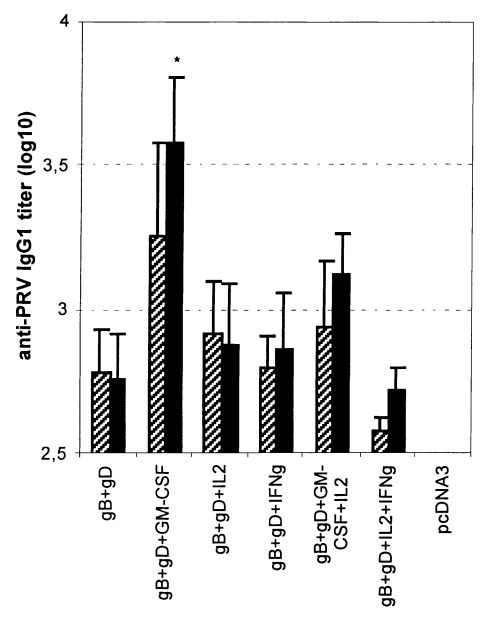

D day 14 day 21

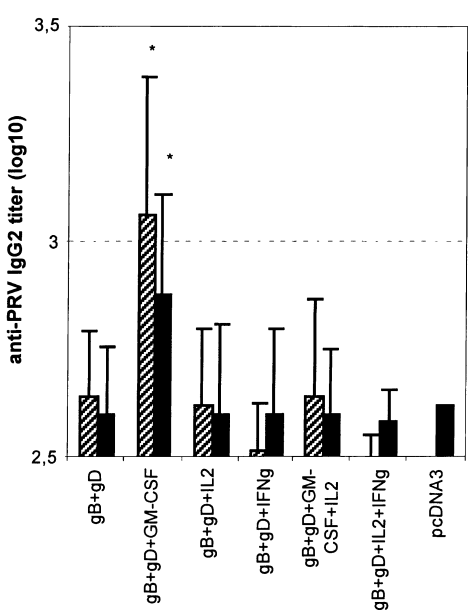

Fig. 3. Anti-PRV IgG1 (left pannel) and IgG2 (right pannel) Ab responses at days 14 and 21 after single DNA vaccination. The anti-PRV IgG subclasses were measured by indirect ELISA using microtitration plates coated with PRV antigen. The titers are expressed in $\log _{10}$ (mean $\pm \mathrm{SD}$ ) of the serum dilution. The * indicates anti-PRV titers which are statistically different $(p<0.05)$ from the group of pigs vaccinated with $\mathrm{gB}+\mathrm{gD}$ alone.

GM-CSF DNA injection. No effect of IL-2 or IFN- $\gamma$ DNA alone on virus excretion was observed (Fig. 4).

Within one week after the challenge, four animals among five in the control (pcDNA3) group had died (Table 1). In contrast, all $\mathrm{gB}+\mathrm{gD}$ DNA vaccinated pigs had survived. In the $\mathrm{gB}+\mathrm{gD}$ vaccinated animals, the weight loss after challenge (MRWG) was reduced as compared to the control pigs. In the two groups of pigs injected with the GM-CSF encoded DNA, either alone or in combination with IL-2, the protection to challenge, as evidenced by weight gains, was increased, as compared to pigs vaccinated with $\mathrm{gB}+\mathrm{gD}$ DNA alone. Thus, the mean relative weight gains were increased and the $\Delta \mathrm{G} 7$ criterion for resistance was twice as high (1.40 and 1.34, as compared to 0.71; Table 1). Other

Table 1

Body weight changes and mortality after challenge infection of pigs vaccinated once with DNA

\begin{tabular}{llrl}
\hline & MRWG $^{\text {a }}$ mean $\pm \mathrm{SD}$ & $\Delta$ G $^{\mathrm{b}}$ & Mortality \\
\hline $\mathrm{gB}+\mathrm{gD}$ & $-1.11 \pm 0.81$ & 0.71 & $0 / 5$ \\
$\mathrm{gB}+\mathrm{gD}+\mathrm{GM}-\mathrm{CSF}$ & $-0.42 \pm 0.47^{\mathrm{c}}$ & 1.40 & $0 / 5$ \\
$\mathrm{gB}+\mathrm{gD}+\mathrm{IL} 2$ & $-2.23 \pm 0.63$ & -0.41 & $2 / 5$ \\
$\mathrm{gB}+\mathrm{gD}+\mathrm{IFN} \gamma$ & $-1.80 \pm 0.77$ & 0.02 & $3 / 5$ \\
$\mathrm{gB}+\mathrm{gD}+\mathrm{GM}-\mathrm{CSF}+\mathrm{IL} 2$ & $-0.48 \pm 0.23^{\mathrm{c}}$ & 1.34 & $0 / 5$ \\
$\mathrm{gB}+\mathrm{gD}+\mathrm{IL} 2+\mathrm{IFN} \gamma$ & $-1.99 \pm 0.43$ & -0.17 & $0 / 5$ \\
pcDNA3 & $-1.82 \pm 0.40$ & & $4 / 5$ \\
\hline
\end{tabular}

${ }^{a}$ The mean relative weight gain (MRWG) was calculated between day 21 and day 28 (one week after PRV challenge) or the day of death. The results are expressed in percentage of weight (mean \pm SD).

${ }^{\mathrm{b}} \triangle \mathrm{G} 7$ represents the difference between the MRWG of vaccinated against PRV and control pigs (pcDNA3).

${ }^{c}$ Significantly different $(p<0.05)$ from the $\mathrm{gB}+\mathrm{gD}+\mathrm{IL} 2$ treated group. 


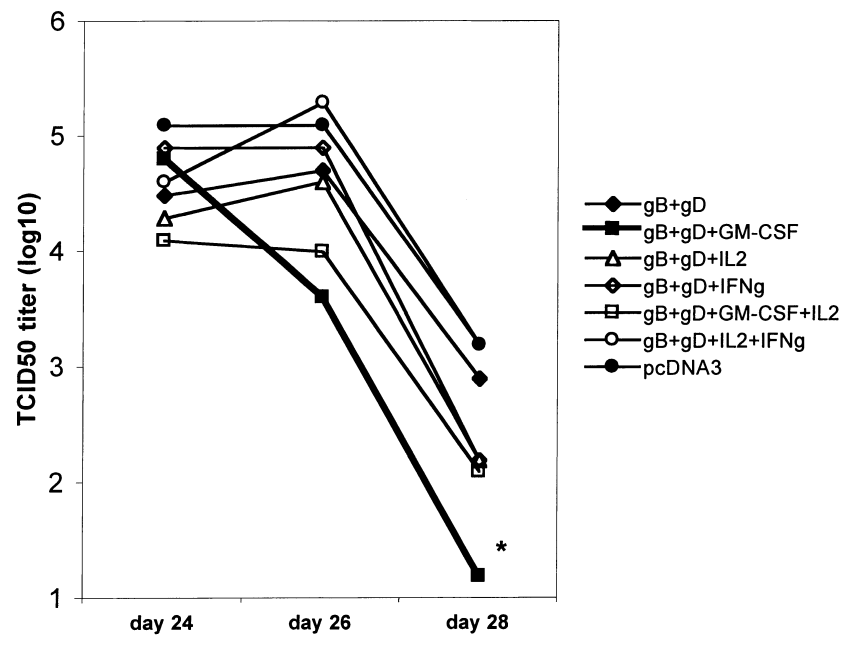

Fig. 4. Nasal virus excretion titers after challenge infection of DNA vaccinated pigs. The virus content in nasal swabs were determined on swine kidney cell line. Titers were expressed as $\log _{10} \mathrm{TCID}_{50} / \mathrm{ml}$ nasal secretion (mean $\pm \mathrm{SD}$ ). The * indicate titers which are statistically different $(p<0.05)$ from the group of pigs vaccinated with $\mathrm{gB}+\mathrm{gD}$ alone.

combinations of PRV DNA and other cytokines (IL-2 and IFN- $\gamma$ ) had no positive impact on the protection. On the contrary, IL-2 alone or in combination with IFN- $\gamma$ even enhanced weight losses.

\section{Discussion}

Cytokines play a critical regulatory role in the development of an immune response. Results published to date clearly show that cytokines as well as co-stimulatory molecules expressed by vector DNA can modulate and improve the immune response to DNA immunization (Pasquini et al., 1997). Molecules that affect antigen presentation, such as GM-CSF, cause a clear increase of both T- and B-cell responses (Tao and Levy, 1993; Sin et al., 1998). More broadly, a large number of cytokines, such as IL-2, IL-4, IL-12, IFN- $\gamma$, GM-CSF have been shown to be capable of enhancing various immune responses when administered along with DNA vaccines against infectious diseases (Pasquini et al., 1997). In the present report, we show that the co-administration of DNA encoding porcine GMCSF improved the efficacy of DNA $\mathrm{gB}$ and $\mathrm{gD}$ vaccine to PRV, in the natural host. The GM-CSF adjuvant effect was characterized by an earlier and higher IgG1 and IgG2 antiPRV Ab response, a reduced and shorter virus excretion after challenge, and an improved protection to the challenge with a fully virulent NIA-3 PRV strain. In contrary, codelivery of DNA encoding IL-2 or IFN- $\gamma$ had no positive effects, but even had negative effects on protection to the challenge. Thus, our data confirm results on DNA vaccination to the rabies virus, in which co-injection of plasmids encoding mouse GM-CSF and virus glycoprotein enhanced B- and Th-cell responses to the virus, while co-inoculation with a 
plasmid expressing IFN- $\gamma$ resulted in a decreased immune response (Xiang and Ertl, 1995).

Several published results demonstrate the efficacy of DNA vaccination in pigs (Beard and Mason, 1998), including to PRV infection (Le Potier et al., 1997; Gerdts et al., 1997; van Rooij et al., 1998), however this is to our knowledge the first report showing a significant adjuvant effect of GM-CSF to PRV DNA vaccine in pigs. In addition, this protective effect to a fully virulent challenge was obtained after only a single DNA injection, while previous data implied repeated injections. Co-delivery of DNA encoding GM-CSF may therefore constitute a potent and inexpensive way to increase vaccine efficacy by a single injection. It is worth emphasizing that the level of protection, as quantified by the $\Delta \mathrm{G} 7$ standardized criterion (Stellman et al., 1989), obtained in GMCSF injected animals, approached the protection provided by inactivated PRV vaccines (Stellman et al., 1989) and exceeded the regulatory minimum requirements for a commercial vaccine $(\Delta \mathrm{G} 7>1.2)$.

We did not observe any positive effect of IL-2 or IFN- $\gamma$ DNA administration, on PRV vaccination. There are several data in pigs showing adjuvant effects of recombinant IL-2 and IFN- $\gamma$ on classical vaccines, including PRV vaccines (reviewed by Blecha, 1997; Vandenbroeck et al., 1998). It is therefore difficult to determine the reasons for this unexpectedly null or even negative biological effect. We have confirmed by in vitro expression experiments that both constructs were indeed active. The absence of their in vivo effects may be due to the protocol of cytokine administration (multiple administrations of recombinant cytokines as published before, versus a single administration of plasmid in our study) or to the nature of the immunogens and challenge models used (inactivated PRV used by Vandenbroeck et al., 1998, as compared to $\mathrm{gB}+\mathrm{gD}$ plasmids in our study) or to the level of in vivo cytokine expression. In order to fully investigate the potential activity of IL-2 and IFN- $\gamma$ in DNA vaccination, further experiments will be needed in which various amounts of cytokine DNA will have to be injected.

In our experiments, it was also interesting to note that, although IL-2 abolished the GM-CSF induced effects on Ab response and virus excretion in the combined IL-2 plus GM-CSF DNA injected pigs, it had no negative impacts on protection $(\Delta \mathrm{G} 7)$ from the challenge. This result, which deserves further analysis, may suggest a positive effect of IL-2 on clinical signs, without effects on Ab production, and therefore possibly through effects on cell-mediated immunity.

Our present data demonstrate the usefulness of cytokine DNA administration to improve single DNA vaccination in pigs. Future experiments will focus on the use of other potentially important cytokines, as well as on the association of cytokines, and the way to increase their in vivo level of expression.

\section{Acknowledgements}

This work was supported by the European grant FAIR 96-1317. We thank M. Zimmermann for the neutralization assay and M. Blanchet and A. Brun for their outstanding management of the pig experiment, and F. Moysan and the animal caretakers of Merial Lyon Gerland Laboratory for their help. 


\section{References}

Arai, K.F.L., Miyajima, A., Miyatake, S., Arai, N., Tokota, T., 1990. Cytokines: Coordinators of immune and inflammatory responses. Annual Rev. Biochem. 59, 783-836.

Babiuk, L.A., Lewis, P.J., van Drunen Little-van Den Hurk, S., Tikoo, S., Liang, X., 1998. Nucleic acid vaccines: veterinary applications. Current Topics Microbiol. Immunol. 226, 90-106.

Beard, C.V., Mason, P.W., 1998. Out of the farm with DNA vaccines. Nature Biotechnology 16, 1325-1328.

Blecha, F., 1997. Cytokine applications in pigs. In: Schijns, V.E.C.J., Horzinek, M.C. (Eds.), Cytokines in veterinary medicine, CAB Internat., 129-137.

Charley, B, Petit, E., Leclerc, C, Stefanos, S, 1985. Production of porcine Interleukin-2 and its biological and antigenic relationships with human Interleukin-2. Immunology Letters 10, $121-126$.

Chen, T.T., Tao, M.H., Levy, R., 1994. Idiotype/cytokine fusion proteins as a cancer vaccines. Relative efficacy of IL-2, IL-4 and granulocyte-macrophage colony-stimulating factor. J. Immunol. 153, 4775-4787.

Gerdts, V., Jons, A., Makoschey, B., Visser, N., Mettenleiter, T.C., 1997. Protection of pigs against Aujeszky's disease by DNA vaccination. J. Gen. Virol. 78, 2139-2144.

Haynes, J.R., McCabe, D.E., Swain, W.F., Widera, G., Fuller, J.T., 1996. Particle-mediated nucleic acid immunization. J. Biotechnol. 44, 37-42.

Hohlfeld, R., Engel, A.G., 1994. The immunology of muscle. Immunol. Today 15, 269-274.

Inumaru, S., Takamatsu, H., 1995. cDNA cloning of porcine granulocyte-macrophage colony-stimulating factor. Immunol. Cell Biol. 73, 474-476.

Inumaru, S., Kokuho, T., Denham, S., Denyer, M.S., Momotani, E., Kitamura, S., Corteyn, A., Brookes, S., Parkhouse, R.M.E., Takamatsu, H., 1998. Expression of biologically active recombinant porcine GM-CSF by baculovirus gene expression system. Immunol. Cell Biol. 76, 195-201.

Kim, J.J., Bagarazzi, M.L., Trivedi, N., Hu, Y., Chatergoon, M.A., Dang, K., Mahalingam, S., Agadjanyan, M.G., Boyer, J.D., Wang, B., Weiner, D.B., 1997. Engineering of in vivo immune responses to DNA immunization via co-delivery of costimulatory molecule genes. Nature Biotechnol. 15, 641-645.

Lefèvre, F., Martinat-Botté, F., Locatelli, A., Niu, P.D., Terqui, M., La Bonnardière, C., 1998. Intrauterine infusion of high doses of pig trophoblast interferons has no antiluteolytic effect in cyclic gilts. Biol. Reprod. 58, 1026-1031.

Le Potier, M.F., Monteil, M.F., Houdayer, C., Eloit, M., 1997. Study of the delivery of the gD gene of pseudorabies virus to one-day-old piglet by adenovirus or plasmid DNA as ways to by-pass the inhibition of immune response by colostral antibodies. Vet. Microbiol. 55, 75-80.

Maliszewski, C.R., Schoendorn, M.A., Ceretti, D.P., 1988. Bovine GM-CSF: molecular cloning and biological activity of the recombinant protein. Mol. Immunol. 25, 843-850.

Mettenleiter, T.C., 1996. Immunobiology of pseudorabies (Aujeszky's disease). Vet. Immunol. Immunopath. 54, 221-229.

Moore, M.A.S., 1991. The clinical use of colony stimulating factors. Annual Rev. Immunol. 9, 159-191.

Nicola, N.A., 1989. Hemopoietic cell growth factors and their receptors. Annual Rev. Biochem. 58, 45-77.

Pasquini, S., Xiang, Z., Wang, Y., He, Z., Deng, H., Blaszczyk-Thurin, M., Ertl, H.C., 1997. Cytokines and costimulatory molecules as genetic adjuvants. Immunol. Cell. Biol. 75, 397-401.

Sin, J.I., Kim, J.J., Ugen, K.E., Ciccarelli, R.B., Higgins, T.J., Weiner, D.B., 1998. Enhancement of protective humoral (Th2) and cell-mediated (Th1) immune responses against herpes simplex virus-2 through codelivery of granulocyte-macrophage colony-stimulating factor expression cassettes. Eur. J. Immunol. 28, 3530-3540.

Steeg, P.S., Moore, R.N., Johnson, H.M., Oppenheim, J.S., 1982. Regulation of murine macrophage Ia antigen expression by a lymphokine with immune interferon activity. J. Exp. Med., 1780-1793.

Stellman, C., Vannier, P., Chappuis, G., Brun, A., Dauvergne, M., Fargeaud, D., Bugand, M., Colson, X., 1989. The potency testing of pseudorabies vaccines in pigs. A proposal for a quantitative criterion and a minimum requirement. J. Biol. Standard 17, 17-27.

Tao, M.H., Levy, R., 1993. Idiotype/granulocyte-macrophage colony-stimulating factor fusion protein as a vaccine for B-cell lymphoma. Nature 362, 755-758.

Vandenbroeck, K., Nauwynck, H., Vanderpooten, A., Van Reeth, K., Goddeeris, B., Billiau, A., 1998. Recombinant porcine IFN- $\gamma$ potentiates the secondary IgG and IgA responses to an inactivated suid 
herpesvirus-1 vaccine and reduces postchallenge weight loss and fever in pigs. J. Interferon Cyt. Res. 18, 739-744.

Vandeputte, J., Chappuis, G., Fargeaud, D., Précausta, P., Guillemin, F., Brun, A., Desmettre, P., Stellmann, C., 1990. Vaccination against pseudorabies with glycoprotein $\mathrm{gI}^{+}$or glycoprotein $\mathrm{gI}^{-}$vaccine. Am. J. Vet. Res. 51, 1100-1106.

van Rooij, E.M.A., Haggmans, B.L., de Visser, Y.E., de Bruin, M.G.M., Boersma, W., Bianchi, A.T.J., 1998. Effect of vaccination route and composition of DNA vaccine on the induction of protective immunity against pseudorabies infection in pigs. Vet. Immunol. Immunopath. 66, 113-126.

Webster, R.G., Fynan, E.F., Santoro, J.C., Robinson, H., 1994. Protection of ferrets against influenza challenge with a DNA vaccine to the haemagglutinin. Vaccine 12, 1495-1498.

Xiang, Z., Ertl, H.C., 1995. Manipulation of the immune response to a plasmid-encoded viral antigen by coinoculation with plasmids expressing cytokines. Immunity 2, 129-135.

Yankaucka, M.A., Morrow, J.E., Parker, S.E., Abai, A., Rhodes, G.H., Dwarki, V.J., Gromkowski, S.H., 1993. Long-term anti-nucleoprotein cellular and humoral immunity is induced by intramuscular injection of plasmid DNA containing the NP gene. DNA Cell Biol. 12, 771-776. 